\title{
Bajorai baltarusiškų Lietuvos Didžiosios Kunigaikštystės pavietų žemès teismo knygose. Teisinis aspektas
}

\author{
DARIUS VILIMAS \\ Lietuvos istorijos institutas, Kražiu g. 5, LT-01108 Vilnius \\ El. paštas: dariusvilimas@hotmail.com
}

\begin{abstract}
Straipsnyje pristatomas LDK dabartinių „baltarusiškų“ pavietų XVI a. paskutiniojo trečdalio žemės teismo knygų kompleksas, saugomas Baltarusijos NIA Minske. Apibūdinama išlikusios medžiagos chronologija ir lokalizacija, taip pat išlikusių knygų tematinis turinys, jų teisminiai įrašai. Aptarta istoriné medžiaga sudaro prielaidas tolesniam kokybiniam šio šaltinių komplekso tyrimui.
\end{abstract}

Raktažodžiai: LDK pavietų žemès teismai, žemės teismų knygų sandara, teisinè kultūra, LDK bajorija

\section{ISTORINIS KONTEKSTAS}

Lietuvos Didžiosios Kunigaikštystès (LDK) pavietų žemės teismų įkūrimas buvo ilgas ir sudètingas procesas, prasidejjęs dar XVI a. 4-ajame dešimtmetyje, kai I Lietuvos Statute 1529 m. bajorijai buvo numatyta galimybė dalyvauti regioninių didžiojo kunigaikščio vietininkų teismų darbe. Nuo to amžiaus 5-ojo dešimtmečio pradžios kai kuriuose valstybès administraciniuose centruose veikè Statute numatyti vadinamieji „žemés teismai“, iš valdovo vietininkų teismo pamažu tapę išsodintųjų (cyдьu высаженые), arba parinktųjų, teisėjų teismu. Pradètos reguliariai vesti tų teismų knygos rodo, kad iš esmès senasis vadinamasis „žemès“ teismas (iki II Lietuvos Statuto prièmimo) buvo pilies teismo sinonimas, o pats teismo pavadinimas tada dar nebuvo nusistovẻjęs. Tačiau bajorijos tai jau netenkino, ji turejo sektiną precedentą - Lenkijos bajorų teismus. Ten jau senokai veikè nepriklausomas žemès teismas. Dar daugiau - tokie teismai XVI a. pirmojoje pusejje buvo ịkurti formaliai LDK priklausančioje Palenkès vaivadijoje, kurioje veikè lenkų teisè ir skirtingi nei likusioje LDK teritorijoje teismai. Brendo esmine teismo sistemos reforma, sutapusi su kitomis to meto valstybinėmis reformomis.

Antrojoje XVI a. pusėje Lietuvos Didžioji Kunigaikštystė įžengè ị reformų epochą. Atejjo laikas reformuoti valstybės administraciją, teismą ir savivaldos sandarą. Tikroji žemès teismo istorija prasideda nuo $1564 \mathrm{~m}$. Bielsko privilegijos, teisminiu aspektu sulyginusios visos bajorijos luomo atstovus ir leidusi pradèti teismo reformą. Po pusantrų metų priimtas ir ìsigaliojęs II Lietuvos Statutas (LS) jau užtvirtino pakitusią teismų sandarą, be didesnių korekcijų egzistavusią du šimtmečius. 
Kuo teismų reforma buvo naudinga paprastiems bajorams? Kiekviename pavieto ar žemès centre ịsteigti bajoriški žemès ir pakamario teismai. Dar buvo ir pilies teismai, tačiau jie liko valdovo administracijos žinioje, pilies teismo pareigūnai būdavo skiriami vaivados, o jam paliktos spręsti tik kriminalinès bylos. Teismas priartėjo prie kiekvieno paprasto bajoro, kuris žinojo, kad jis formaliai galès teistis net ir su didiku. Kiekvienas juridinis bajoro veiksmas ar finansinè operacija galèjo būti santykinai greitai užfiksuotas pilies (jie dirbo kas mènesị po dvi savaites) arba žemės teisme. Kadangi renkamo žemės teismo prestižas buvo didesnis už skiriamų pareigūnų pilies teismą, labai dažnai iš pilies teismo knygų i̇ žemès būdavo peraktuojami ịvairūs notariniai ịrašai arba vaznių pareiškimai, nes žemès teismas dirbo tik tris sesijas per metus. Kiekviename teisme pareigūnų skrynioje buvo saugomos teismo knygos, kuriose buvo galima įrašyti savo dokumentus nesibaiminant, kad vieno ar kito juridinio akto originalas gali sudegti gaisre - išrašai iš jų turejo tokią pačią galią kaip ir jų originalai. Taigi teismų reforma ir jų kompetencijos atskyrimas - žemès teismui liko civilinès, pilies teismui - kriminalinès, o pakamario - valdų ribų ginčai - ịvedè daug daugiau tvarkos ị teisès dalykus. Bajoras žinojo, kada ir kur dirbs vienas ar kitas pavieto teismas. Jis galejo tikètis ne tik greitesnio teisingumo ịvykdymo ar saugesnio sau vertingu dokumentų kopijų peraktavimo. Palengva keitèsi ir paties bajoro mąstysena - šalia pavietų seimelių žemès teismai tapo pagrindine vieta, kur viešojoje erdveje būdavo sprendžiami bajorų tarpusavio ginčai, tvirtinamos jų atliktos finansinès operacijos ar kiti jiems svarbūs reikalai. Net paprastas išplūdimas susitikus gatvèje, t. y. smulkus chuliganizmas, būdavo skrupulingai fiksuojamas. Lygiai taip pat detaliai būdavo fiksuojama ne tik teisminio ginčo eiga, bet ir po jo sekęs susitaikymas ar teismo nuosprendis. LDK bajorai žemès teismuose igyvendino savo seną svajonę - teismo nepriklausomybès nuo didžiojo kunigaikščio ir didikų vietininkų principą. Kartu tokių teismų ịkūrimas ir darbas buvo labai vertinga teisinès kultūros lavinimosi mokykla. Žemès teismo knygos - neįkainojamos vertès to bajorų gyvenimo teisminès briaunos atspindys.

\section{TYRIMO OBJEKTAS IR JO ISTORIOGRAFIJA}

Žinoma, kad LDK naujojo tipo žemès teismo darbas neprasidejo kitą dieną po Bielsko privilegijos prièmimo 15640701 . Nors tokių teismų darbą numatyta pradèti tų metų Šv. Martino dieną (1564 11 11), iš tikrųjų tokios įstaigos ịkūrimui reikèjo papildomai techniškai pasiruošti (pavietų atribojimas, darbo vietų parinkimas, pastatų teismui statyba ir pan.), todèl kiekviename paviete jis buvo ịkurtas atskirai ir skirtingu metu tarp $1565 \mathrm{~m}$. pavasario ir 1566 m. pradžios. Štai pavietų atribojimas LDK dalyje, esančioje dabartinèje Baltarusijos teritorijoje, fiksuojamas tarp 1565 m. balandžio (Ašmena, Minskas, Brasta) ir 1566 m. sausio (Pinskas). Tai mums įrodo daugiausia išlikęs kelių pavietų atribojimas ir tik vienu atveju turime išlikusį žemès teismo ịkūrimo procedūros aprašymą, publikuotą Slanimo žemès teismo knygoje $1565 \mathrm{~m}$. birželio $1 \mathrm{~d}$. Kadangi išliko ir keletas ikireforminių Gardino „žemès“ teismo knygų, tikètina, kad tai galèjo būti aprašyta ir to pavieto teismo knygose, bet tam neturime įrodymų. Atrodo, kad ịkurti naująj žemès teismą trukdè ir Livonijos karas - rytiniuose valstybès pakraščiuose jis vẻlavo. Oršoje žemès teismas dirbo tik nuo 1567 m. pavasario, o Polocke, tuo metu (nuo 1563 m.) užimtame maskvėnų, pavieto žemès teismas ịkurtas tik $1570 \mathrm{~m}$. vasarą ir veikẻ neokupuotoje teritorijoje (teigiama, kad Lepelyje).

Po Liublino unijos LDK teritorijoje liko 9 vaivadijos ar joms prilygstantys administraciniai dariniai, kuriuos sudarė 22 pavietai. Pavietų skaičius vaivadijoje svyruodavo nuo 
penkių (Vilniaus vaivadija) iki vieno (Polockas, Mstislavlis, Žemaitija). Kadangi maždaug du trečdaliai tuometès valstybès teritorijos dabar priklauso Baltarusijos Respublikai, visai nenuostabu, kad maždaug tokia pati pavietų ir vaivadijų centrų dalis yra jos teritorijoje. Lietuvos Respublikoje dabar yra Vilnius, Ukmergè, Trakai, Kaunas, Panevèžys ir Raseiniai. Baltarusijos Respublikoje - Minskas, Gardinas, Lyda, Ašmena, Breslauja, Naugardukas, Slanimas, Valkaviskas, Brasta, Pinskas, Vitebskas, Polockas, Orša, Mstislavlis, Mozyrius, Riečica.

Visų LDK rankraštinių teismo knygų likimą iki XX a. pradžios yra aprašęs R. Mienickis [48]. Vèliau jos vèl vežiotos, pagaliau atsidalytos teritoriniu principu pačios tuometès SSSR viduje. Išlikusios rankraštinès tų „baltarusiškų“ pavietų žemės teismų knygos po Antrojo pasaulinio karo $1951 \mathrm{~m}$. pervežtos ị Baltarusiją, dauguma - ị Minską, kitos - Gardiną (vèliau, 1964 m., Gardino, Slanimo pavieto knygos irgi buvo pervežtos i Minską, todèl dabar visas jų kompleksas yra Baltarusijos NIA). Iš XVI a. baltarusiško LDK arealo išliko keturių pavietų žemès teismo knygos.

Darbe nagrinėjama keliasdešimt ankstyvųjų (1565-1600m., 41 vnt.) rankraštinių LDK pavietų žemès teismo knygų, saugomų Baltarusijos NIA (žr. 1 lentelę). Šiame straipsnyje taip pat nagrinejjama ir poros jau publikuotų LDK žemés teismo knygų (Slanimas) medžiaga. Taigi čia aptarsime šių pavietų žemės teismų knygas: 7 Brastos, 14 Gardino, 17 Slanimo ir 3 Vitebsko. Dauguma jų sovietmečiu buvo restauruotos, padaryti jų mikrofilmai. Tyrimą iš dalies palengvina faktas, kad nuo XX a. 9-ojo dešimtmečio pabaigos BNIA sudaromi seniausių pavietų teismų knygų vidiniai aprašai.

LDK pavietų teismų knygų turinys nèra daug tyrinètas. XX a. pradžioje keliasdešimt Žemaitijos žemės teismo knygų, saugomų Vilniaus centriniame senųjų aktų archyve, turinị aprašè I. Sprogis ir jo pagalbininkai [71]. Dar prieš tris dešimtmečius bandyta tirti žemès teismų genezę, naudotasi ir Gardino teismo knygomis [44]. Vèliau detaliai aptartos XVI a. vidurio ikireforminès Vilniaus „pilies“ teismo knygos [45-46]. Ukrainiečių istorikè Natalija Starčenko tyrinèjo Voluinès pilies teismų darbą XVI a. pabaigoje [80-81]. Žemaičių bajorijos šeiminius ryšius XVI a. pabaigoje nagrinejo R. Trimonienė [52]. Tirta ir Upytès pavieto žemès teismo kasdienybė [6]. Geografiškai ir chronologiškai artimą N. Starčenkos tyrimui temą kitu rakursu tyrinèjo V. Poliščiukas [72-73]. Iš kitų Lietuvos istorikų, tyrinèjusių Žemaitijos teismo realijas, būtina paminèti E. Saviščevą [51] ir J. Drungilą [42]. Teismo knygų sandarą bandè tirti I. Valikonytė [55]. Baltarusiškų pavietų žemès teismo knygų sudètis iki $1600 \mathrm{~m}$. anksčiau tiesiogiai tirta ir Lietuvoje [61]. Vèlyvesnio laikotarpio (XVII a.) Breslaujos žemès teismo knygas yra aptaręs H. Lulewiczius [47]. Pastaraisiais metais baltarusiškų pavietų žemès teismų knygas tyrinėja ir baltarusių istorikai A. Radamanas [74], A. Šalanda [76-77], N. Sliž [78] ir kiti [66]. Leidžiami ir tematiniai dokumentų iš tų knygų rinkiniai [75]. Pagaliau, praèjus beveik šimtmečiui nuo ABAK serijos pabaigos (1915), pasirodè ir pirmoji naujos teismo knygos publikacija, tiesa, Ukrainoje [70]. Apie tai dažnai rašoma ir Lenkijoje leidžiamose LDK teisès istorijos sintezėse [63], jau yra ir specializuotų studijų, skirtų atskirų Lenkijos žemių teismams [49].

Baltarusijos NIA yra 41 seniausia LDK pavietų žemès teismų (iki $1600 \mathrm{~m}$.) knyga. Iš jų Brastos pavieto - 7, Gardino pavieto - 14, Slanimo - 17 ir Vitebsko - 3. Jų būklè labai skirtinga, daugelis jų yra „restauruotos“ blizgiu perforaciniu popieriumi, apnykusios ir apiblukusios, todèl dalis teksto jau prarasta. Kita vertus, kaip jau minèta, beveik visų jų yra vidiniai aprašai, o daugelio iš jų išduodami tik mikrofilmai, padaryti praejjusio amžiaus 7-8 dešimtmečiu. 
Brastos pavietas. Ši pavietą reprezentuoja išlikusios septynios žemės teismo knygos [1-7], chronologiškai tarpusavyje sumaišytos. Pirmosios penkios to fondo aktų knygos prasideda 1580 m., bet ankstyviausia yra fondo knyga Nr. 61, vadinamoji „einamųjų reikalų knyga“, kurioje sudetos kelios 1566-1604 m. teismo sesijos. Knygoje Nr. 63 (irgi „einamųjų reikalų“) yra 1597 m. žemės teismo knyga. Beje, pirmojoje paminėtoje „einamųjų reikalų“ teismo knygoje irgi yra 1597 m. žemės teismo įrašų. Minsko NIA yra likusios ir to meto Brastos pilies teismo knygos. Gardino pavietą reprezentuoja keturiolika išlikusių 1566-1601 m. žemès teismo knygų [8-21]. Dvi ankstyviausios Gardino „žemès“ teismo knygos (1556-1559) ì mūsų aptarimą neįtrauktos, nes jos yra priešreforminès. Kai kurie šio pavieto ikireforminio žemès teismo darbo aspektai jau yra aptarti ABAK serijoje - keliuose jos tomuose publikuotos senosios teismo knygos ar jų fragmentai [24]. Poreforminès žemès teismo knygos didelès, labai skirtingai išsilaikiusios, jų įrašai beveik be pertraukų apima laikotarpi iki XVI a. pabaigos ir toliau. Kaip ir Brastoje, Gardine, be žemès teismo knygu, yra išlikusios ir to paties laikotarpio pilies teismo knygos. Slanimo paviete [22-38], kaip ir Gardine, yra išlikusi ir ikireforminè knyga, publikuota minèto ABAK serijos XXII tomo pradžioje [p. 1-146]. Toliau jame yra dvi Slanimo poreforminės žemės teismo knygos. Iš XIX a. Vilniaus centrinio senųjų aktų archyvo katalogo ir dabartinio Baltarusijos NIA Minske aprašų aiškejja, kad šios dvi knygos neina viena po kitos. Dabartiniame Slanimo žemès teismo knygų sąraše tarp jų yra dar viena 1567-1570 m. knyga, o VCA kataloge jos turèjo Nr. 7675 ir 7678, t. y. tarp jų turejo būti dar dvi knygos. Iš viso jų Slanime šiuo laikotarpiu yra 17, nes ankstyvųjų ikireforminių, dar ABAK skelbtų knygų dabar archyve nèra. Pirmoji poreforminė Slanimo žemès teismo knyga savo struktūra ir turiniu primena pirmąją Kauno žemės teismo knygą [64]. Nors ten jau teisia naujasis žemès teismas - teisèjas, pateisejjis ir raštininkas - ir jos pradžioje net aprašyta to teismo ịkūrimo ceremonija, tos knygos ịrašai eina vienu „srautu“, panašiai kaip prieš tai buvusioje ir ten pat publikuotoje 1555-1565 m. „žemès“ (faktiškai ikireforminejje pilies) teismo knygoje, o joje vyrauja juridiniai-teisminiai įrašai - net 265 iš 291. Antroji publikuota [65] poreforminè $1570 \mathrm{~m}$. Slanimo žemès teismo knyga (dabar ji Minske fondo apraše pažymèta Nr. 3) yra gerokai trumpesnè, bet joje daugiau notarinių įrašų - 63 iš 83. Nuo XVI a. 8-ojo dešimtmečio Slanimo žemès teismo knygos, kaip ir Gardine, iki amžiaus pabaigos eina beveik pamečiui, išskyrus bekaralmečius, kai vietoje iprastinių pavietų teismų veikè jungtiniai kaptūriniai teismai. Vitebsko paviete žemès teismo knygos išliko tik nuo paskutiniojo XVI a. dešimtmečio [39-41]. Iš šio laikotarpio jų yra trys, apie įdomesnes jų vietas dar XIX a. pabaigoje I. Lappo yra parašęs nemažą studiją [67]. Jos apima 1594-1598 m. laikotarpi, yra vidutinio dydžio, gana prastai išlikusios, nèra mikrofilmų.

Apibendrinant visų keturių vadinamųjų „baltarusiškų“ LDK pavietų knygų skaičių ir chronologinị išsidèstymą, galima teigti, kad maždaug nuo XVI a. 9-ojo dešimtmečio vidurio tuose (trijuose, be Vitebsko) pavietuose jau galima kalbėti apie ritmingą žemès teismų funkcionavimą.

Kas buvo įrašoma į žemès teismo knygas? Jau esame rašę, kad margiausia ir įdomiausia yra notarinè teismo knygų ịrašų dalis, kurioje aptinkame ịvairiausių ir netikéčiausių ịrašų. Labai įdomios ir ịvairios teismo procesų kolizijos. Pavyzdžiui, jau rašyta apie kriminalines idomybes [56] ar teisminès kultūros atspindžius Kauno paviete [59], Upytės pavieto žemès teismo elitą ir žemės teismo kasdienybę prieš III Lietuvos Statuto prièmimą [60]. Panašios yra ir baltarusiško LDK arealo pavietų žemès teismo knygos. 
1 lentelè. Seniausių LDK baltarusiškų pavietų žemės teismų knygos ir jų dydis (iki 1600 m.)

\begin{tabular}{|c|c|c|c|c|c|c|}
\hline Eil. Nr. & Pavietas ir kn. Nr. & Fondo Nr. BNIA & Metai & Lapų / psl. sk. & l̨rašų sk. & Sesijų sk. \\
\hline 1. & Slanimo I & 1785 & 1565-1566 & 406 & 293 & „ištisinè \\
\hline 2. & Gardino III & 1755 & $\begin{array}{c}1566-1567 \\
(1597)\end{array}$ & $210+27$ & $114+14$ & $3+1$ \\
\hline 3. & Brastos 61-oji & 1741 & $\begin{array}{c}1566-1597 \\
(1604)\end{array}$ & $209+171$ & $109+79$ & $5+1$ \\
\hline 4. & Slanimo II & 1785 & $1567-1570$ & 169 & 175 & 4 \\
\hline 5. & Gardino V & 1755 & 1567 & 120 & 108 & „ištisinè \\
\hline 6. & Gardino IV & 1755 & $1568-1570$ & 462 & 267 & 3 \\
\hline 7. & Slanimo III & 1785 & 1570 & 226 & 84 & 1 \\
\hline 8. & Gardino VI & 1755 & 1571 & 1025 psl. & 304 & 3 \\
\hline 9. & Slanimo IV & 1785 & 1571 & 134 & 42 & 1 \\
\hline 10. & Slanimo V & 1785 & 1575 & 95 & 49 & 1 \\
\hline 11. & Gardino VII & 1755 & 1578-1579 & 477 & 216 & 3 \\
\hline 12. & Brastos I & 1741 & 1580 & 411 & 194 & 2 \\
\hline 13. & Slanimo VI & 1785 & 1581 & 259 & 161 & 1 \\
\hline 14. & Gardino VIII & 1755 & 1581-1582 & 496 & 302 & 3 \\
\hline 15. & Slanimo VII & 1785 & 1583 & 183 & 80 & 1 \\
\hline 16. & Slanimo VIII & 1785 & 1583 & 103 & 66 & 1 \\
\hline 17. & Gardino IX & 1755 & 1583-1584 & 1040 psl. & 261 & 3 \\
\hline 18. & Brastos II & 1741 & 1584 & 270 & 164 & 3 \\
\hline 19. & Gardino X & 1755 & $1585-1586$ & 985 psl. & 194 & 3 \\
\hline 20. & Brastos III & 1741 & 1586 & 311 & 239 & 3 \\
\hline 21. & Slanimo IX & 1785 & 1586 & 138 & 119 & 1 \\
\hline 22. & Slanimo X & 1785 & 1588 & 130 & 103 & 1 \\
\hline 23. & Slanimo XI & 1785 & 1589-1590 & 329 & 263 & 3 \\
\hline 24. & Brastos IV & 1741 & 1590 & 1363 psl. & 457 & 2 \\
\hline 25. & Gardino XI & 1755 & $1591-1592$ & 964 & 428 & 4 \\
\hline 26. & Slanimo XII & 1785 & 1591 & 303 & 246 & 2 \\
\hline 27. & Brastos V & 1741 & 1591 & 330 & 182 & 1 \\
\hline 28. & Gardino XII & 1755 & 1592-1593 & 392 & 183 & 3 \\
\hline 29. & Slanimo XIII & 1785 & 1593-1594 & 209 & 144 & 2 \\
\hline 30. & Gardino XIII & 1755 & 1594-1596 & 864 & 433 & 4 \\
\hline 31. & Vitebsko I & 1751 & 1594 & 163 & 100 & 1 \\
\hline 32. & Slanimo XIV & 1785 & 1595 & 174 & 132 & 1 \\
\hline 33. & Vitebsko II & 1751 & $1595-1596$ & 379 & 228 & 2 \\
\hline 34. & Gardino XIV & 1755 & 1596-1597 & 224 & 129 & 1 \\
\hline 35. & Slanimo XV & 1785 & 1597-1598 & 380 & 252 & 3 \\
\hline 36. & Brastos 63-ioji & 1741 & 1597 & 1106 & 797 & 3 \\
\hline 37. & Gardino XV & 1755 & 1597 & 555 & 288 & 3 \\
\hline 38. & Vitebsko III & 1751 & 1598 & 291 & 194 & 2 \\
\hline 39. & Slanimo XVI & 1785 & 1598 & 288 & 213 & 3 \\
\hline 40. & Slanimo XVII & 1785 & 1599 & 353 & 211 & 2 \\
\hline 41. & Gardino XVI & 1755 & $1599-1601$ & $667+404$ & $326+189$ & 3 \\
\hline
\end{tabular}


2 lentelè. Seniausių LDK baltarusiškų pavietų žemės teismų knygų (iki $1600 \mathrm{~m}$.) turinys

\begin{tabular}{|c|c|c|c|c|c|c|}
\hline $\begin{array}{l}\text { Eilès } \\
\text { Nr. }\end{array}$ & $\begin{array}{l}\text { Pavietas ir } \\
\text { knygos Nr. }\end{array}$ & Metai & $\begin{array}{l}\text { Lapų/psl. } \\
\text { skaičius }\end{array}$ & İrašų skaičius & $\begin{array}{l}\text { Iš jụ teisminių- } \\
\text { proces. }\end{array}$ & $\begin{array}{c}\text { Išjụ } \\
\text { nuosprendžių }\end{array}$ \\
\hline 1. & Slanimo I & $1565-1566$ & 406 & 293 & 257 & 3 \\
\hline 2. & Gardino III & $\begin{array}{c}1566-1567 \\
(1597)\end{array}$ & $\begin{array}{c}210 \\
(+27)\end{array}$ & $\begin{array}{c}114 \\
(+14)\end{array}$ & 54 & 50 \\
\hline 3. & Brastos 61-oji & $\begin{array}{c}1566-1597 \\
(1604)\end{array}$ & $\begin{array}{c}209 \\
(+171)\end{array}$ & $\begin{array}{c}109 \\
(+79)\end{array}$ & 61 & 30 \\
\hline 4. & Slanimo II & $1567-1570$ & 169 & 175 & $?$ & $?$ \\
\hline 5. & Gardino V & 1567 & 120 & 108 & 85 & 0 \\
\hline 6. & Gardino IV & $1568-1570$ & 462 & 267 & 94 & 57 \\
\hline 7. & Slanimo III & 1570 & 226 & 84 & 17 & 16 \\
\hline 8. & Gardino VI & 1571 & 1025 psl. & 304 & 71 & 26 \\
\hline 9. & Slanimo IV & 1571 & 134 & 42 & 3 & 1 \\
\hline 10. & Slanimo V & 1575 & 95 & 49 & 5 & 2 \\
\hline 11. & Gardino VII & $1578-1579$ & 477 & 216 & 50 & 32 \\
\hline 12. & Brastos I & 1580 & 411 & 194 & 94 & 59 \\
\hline 13. & Slanimo VI & 1581 & 259 & 161 & 39 & 13 \\
\hline 14. & Gardino VIII & $1581-1582$ & 496 & 302 & 58 & 30 \\
\hline 15. & Slanimo VII & 1583 & 183 & 80 & 48 & 24 \\
\hline 16. & Slanimo VIII & 1583 & 103 & 66 & 33 & 10 \\
\hline 17. & Gardino IX & $1583-1584$ & 1040 psl. & 261 & 76 & 53 \\
\hline 18. & Brastos II & 1584 & 270 & 164 & 123 & 34 \\
\hline 19. & Gardino X & $1585-1586$ & 985 psl. & 194 & 55 & 28 \\
\hline 20. & Brastos III & 1586 & 311 & 239 & 140 & 86 \\
\hline 21. & Slanimo IX & 1586 & 138 & 119 & 78 & 33 \\
\hline 22. & Slanimo X & 1588 & 130 & 103 & 41 & 22 \\
\hline 23. & Slanimo XI & 1589-1590 & 329 & 263 & 124 & 61 \\
\hline 24. & Brastos IV & 1590 & 1363 psl. & 457 & 233 & 117 \\
\hline 25. & Gardino XI & 1591-1592 & 964 & 428 & 65 & 38 \\
\hline 26. & Slanimo XII & 1591 & 303 & 246 & 133 & 75 \\
\hline 27. & Brastos V & 1591 & 330 & 182 & 95 & 49 \\
\hline 28. & Gardino XII & 1592-1593 & 392 & 183 & 62 & 50 \\
\hline 29. & Slanimo XIII & 1593-1594 & 209 & 144 & 59 & 28 \\
\hline 30. & Gardino XIII & 1594-1596 & 864 & 433 & 143 & 87 \\
\hline 31. & Vitebsko I & 1594 & 163 & 100 & 52 & 6 \\
\hline 32. & Slanimo XIV & 1595 & 174 & 132 & 65 & 32 \\
\hline 33. & Vitebsko II & $1595-1596$ & 379 & 228 & 98 & 16 \\
\hline 34. & Gardino XIV & 1596-1597 & 224 & 129 & 30 & 13 \\
\hline 35. & Slanimo XV & 1597-1598 & 380 & 252 & 126 & 65 \\
\hline 36. & Brastos 63-ioji & 1597 & 1106 & 797 & 379 & 112 \\
\hline 37. & Gardino XV & 1597 & 555 & 288 & 79 & 41 \\
\hline 38. & Vitebsko III & 1598 & 291 & 194 & 78 & 16 \\
\hline 39. & Slanimo XVI & 1598 & 288 & 213 & 102 & 41 \\
\hline 40. & Slanimo XVII & 1599 & 353 & 211 & 94 & 37 \\
\hline 41. & Gardino XVI & $\begin{array}{c}1599-1600 \\
(+1601)\end{array}$ & $667+404$ & $\begin{array}{c}326 \\
(+189)\end{array}$ & 84 & 45 \\
\hline
\end{tabular}


Kaip matome, daugelyje aptariamų žemės teismo knygų vyrauja notariniai įrašai (2 lentelè). Nors kažkokios bendros tendencijos nèra, tačiau netgi tose knygose, kuriose teisminių-procesinių ịrašų yra daugiau, teismo nutartys sudaro nedidelę jų dalį. Didesnę šio tipo įrašų dalị sudaro vaznių ịrašai apie jų atliktus juridinius veiksmus (paskyrimas valdyti, teismo šaukimų ịteikimai, žalos ar nuostolių apžiūrų paliudijimai ir pan.), bajorų skundai bei besibylinėjančių pusių atvykimo ir neatvykimo ị teismą paliudijimai. Pačios nutartys dažniausiai apsiribodavo piniginių baudų arba jų ekvivalento turtu nustatymu, laisvès atėmimo bausmès kalèjime (dažniausiai tai buvo pilies bokštas) buvo retos.

Žemès teismui formaliai priklausè civilinès bylos, kriminalinės bylos buvo paliktos pilies teismams. Tačiau ir žemès teismuose pasitaiko ịrašų, susijusių su žmogžudystėmis, tiesa, tai dažniausia piniginio užmokesčio - galvažudinès mokejjimo - reikalai. Tokiais atvejais be pabaudos būdavo skiriama ir laisvès atėmimo bausmè.

İdomybès. Teisminei knygų daliai priskirtini teismo knygų ịrašai, kaip jau minėjome, išskiriami i gausių procesinių ir dekretinių nutarčių skirsnius. Kadangi žemės teismas buvo daugiau civilinis, net ir teismo nutartys dažniausia apsiribojo (nors ir ne šimtu procentų) piniginių baudų arba (rečiau) laisvès atėmimo skyrimu. Šịkart iš teismo nutarčių ịrašų norètume atkreipti dèmesị i gana specifinę ir retą santuokos nutraukimo nutarčių grupę. Aišku, tokios nutartys nedažnos, nors ir dažnesnès stačiatikiškoje LDK teritorijos dalyje (teigti, kad bajorams katalikams tai nebūdinga iš principo, būtų ne visai tikslu). Tačiau net ir čia šie pavyzdžiai pavieniai ir kartais labai įdomūs. Skaitytojų dèmesiui pateikiame keletą tokių ịrašų pavyzdžių. Šalia principinių barnių ir net peštynių randame ir paprastų ginčų dèl turto ar net bažnytinio teismo nutarčių santuokos klausimais.

Štai 15681006 d. Gardino žemès teismas prièmè sprendimą Krynkų miestiečio Sako Belavičiaus byloje su ponu Ivanu Vešanevičiumi dèl to, kad iš namų buvo išvyta jo dukra Motrūna ir nesugrąžinta pasoga. I. Vešanevičius ị tai atkirto, kad Sako dukra jam nebuvo teisèta žmona, t. y. gyveno su juo nesusituokusi (без венц, $a$ ). Kai jis išvijo ją iš namų, visus jos daiktus sugrąžino. Ieškovas norèjo prisiekti, kad daiktai negrąžinti. Bylai paskirta trečia diena, bet tądien S. Belavičius atsièmė visus kaltinimus prieš I. Vešanevičių [9, $22-22 \mathrm{v}]$.

Kartais būdavo tik ginčai be smurto: Gardino pavieto žemionis Stanislavas Ščasnovičius Toločko su žmona Nastasja Ivanovna Meleškovna 15710118 d. apskundė savo uošvị Ivaną Fedorovičių Melešką (Nastasjos tèvą), kad šis, paėmęs į žmonas savo pirmąją žmoną, dabar jau velionę Tomilą Andriejevną Sopotkovną, jai pasižadėjo už kraitị - auksu ir sidabru už 600 kapų lietuviškų grašių - tą sumą savo Gornacko dvare, Gardino paviete. Ją jau išmokèjo dalimis dviem Nastasjos seserims, o trečiosios dalies, t. y. 200 kapų grašių, Nastasjai atiduoti nenori. Gornacko dvarą tuština ir niokoja nieko nepaisydamas, ir net šaukiamas neatvyko i 1570 m. Šv. Mykolo (rudeni) žemès teismo sesiją. Paminètas net $1554 \mathrm{~m}$. raštas, kuriuo I. Meleška ima į žmonas Tomilą ir gauna 300 kapų lietuviškų grašių kraičio, o jai užrašo 600 kapų grašių 1/3 savo dvarų; raštas saugotas pas Tomilos tèvą Andriejų Sopotką, tik po jo mirties buvo pamestas. Žemès teismas, išklausęs ieškovų skundus ir atsakovų atsakymus, priteisè ieškovų naudai 200 kapų lietuviškų grašių. O jei pinigai nebūtų sumokèti, tada turès i̊sileisti ị Gornacko dvarą [11, 147-152].

Trečias nutikimas primena detektyvą: 15670106 d. Grigorijus Kaznačevičius skundžia žentą Andriejų Stryžką, kad šis, sumušęs savo žmoną Maryną Kaznačevną, išvijo ją iš Seinų dvaro ir atsisako sugrąžinti jos turtą (yra jo sąrašas) [10, 2-3]; tų pačių metų vasario 25 d. pavieto vaznys Vosylius Mardasovičius raštiškai pripažįsta Andriejaus Stryžkos ligą 
(sužalojimą?), taip pat užfiksuotas pastarojo skundas žmona Maryna Kaznačevna ir tarnu Grygučiu Montvilavičiumi dèl pasikèsinimo ị jo gyvybę [10, 18-19].

Kitas įdomus atvejis: 15701002 d. Liubka Tišynna Ščastna Stankievičia Rymonda skundžia savo vyrą Ščastną Stankievičių Rymondą, kad šis išvijo ją iš namų; skundas papildytas vaznio paliudijimu. Paaiškejjo, kad Liubka su Ščastnu gyveno daug metų, o už savo kraitị daiktais ir pan. (ji turi jų sąrašą) jis turẻjo jai užrašyti 50 kapų lietuviškų grašių trečiojoje Gluboko dvaro dalyje. Tačiau $15701001 \mathrm{~d}$. jis nežinia kodèl ją išvijo iš namų ir ji iš karto pasiskundè vazniui, buvusiam tame dvare. Vaznys Ilja Miklaševičius patvirtino matęs, kaip 15701001 d. jis siūlèsi jai atiduoti vieną skrynią, bet ji jos nepaèmè, pasakiusi, kad, be skrynios, yra daug kitokių daiktų [9, 263-263v].

Tačiau įdomiausias yra truputi kitoks nutikimas. Jị norètųsi pateikti visą kaip bažnytinės kazuistikos pavyzdị. Gardino XI žemès teismo knygoje aptinkamas [16, 337-339] ịrašas apie Vitebsko vaiskio (vèliau dirbusio žemès teismo teisėju Gardine) Levo Michailovičiaus Sapiegos ir jo žmonos Onos Kapčiūtès (Ganna Kopcevna) skyrybas (žr. priedą), peraktuotas iš stačiatikių arkivyskupo Onisidoro knygų. Vitebsko kariuomeninkas Levas Sapiega, žymiojo kanclerio bendravardis ir amžininkas, Gardine jau tapęs žemès teisèju, peraktuoja savo skyrybų raštą, atsivežtą iš Oršos. Šiuo atveju patys stačiatikių hierarchai duoda leidimą bažnytinėms skyryboms, argumentuodami tai faktu, kad besituokiantieji esą nežinoję, kad yra giminès. Šiuo atveju skyrybas suteiktų ir katalikai, bet mums įdomesnis cituojamo dokumento pabaigoje paminètas faktas, kad savo skyrybų raštus buvę sutuoktiniai užregistravo kažkuriame (nepasakyta, kuriame) Naugarduko pavieto teisme kaip civilinių skyrybų faktą ir tai parode vyskupui Isidorui. Tačiau visos bažnytinès ir civilinès procedūros nepažeistos, netgi minimas grasinimas atskirti nuo Bažnyčios, nors ir atrodo, kad to rašto labiau reikejjo Levui Sapiegai, persikèlusiam ị kitą valstybès pakraštị (iš Vitebsko ị Gardiną) ir sumaniusiam vèl tuoktis, todèl jis ir pasiemęs šio rašto išrašą iš žemès teismo knygų. Tokị spejjimą patvirtina ir dokumente minimas žmonos Onos leidimas buvusiam vyrui vèl tuoktis, pati ji žada tik užbaigti savo gyvenimą. Šio asmens biografinèje diagramoje "Lenkų biografiniame žodyne“ $[50,83-84]$ net neminima pirmoji L. Sapiegos žmona O. Kapčiūtè, o tik antroji - Elena Haraburdaitė, Minsko kaštelionaitė. Beje, ten rašoma, kad gyvenimą L. Sapiega baigė jau kaip kalvinistas. Galbūt čia slypi tikroji skyrybų priežastis?

\section{IŠVADOS}

1. Baltarusijos Nacionaliniame istorijos archyve Minske yra išlikusi keturių „baltarusiškų“ (Brastos, Gardino, Slanimo ir Vitebsko) LDK poreforminių pavietų 41 rankraštinè žemès teismo knyga (iki XVII a. pradžios). Jos pasižymi temų ịvairove, bet turiniu nedaug skiriasi nuo tokių pačių lietuviškos LDK dalies pavietų medžiagos. Šios knygos kiekybiškai ir kokybiškai papildo lietuviškų LDK pavietų žemès teismų knygų medžiagą, padeda susidaryti išsamesnį žemès teismų darbo ir bajorijos veiklos juose vaizdą.

2. Kaip ir lietuviškoje LDK dalyje, taip ir baltarusiškuose valstybès pavietuose žemès teismų knygose esančius įrašus galima suskirstyti į notarinius ir teisminius-procesinius. Notariniai įrašai vyrauja daugelyje čia nagrinėjamų knygų. Pateikti knygų įrašų pavyzdžiai rodo, kad pavieto žemès teismo knygose galejo būti aktuojami ir tokie dokumentai, kurie tiesiogiai nebuvo susiję su teismo funkcijomis arba priklausė kito pavieto teismo kompetencijai. Nors beveik visose žemès teismų knygose yra vienokių ar kitokių teisminiųprocesinių įrašų, dažniausiai teismo sprendimų skaičius nėra didelis ir sudaro nuo 
penktadalio iki trečdalio visų nenotarinių knygų îrašų. Straipsnyje pateikiama retoka žemès teismo įrašų grupe - šeiminiai ginčai, vienas skyrybų raštas peraktuojamas visas.

3. Rankraštinès LDK pavietų žemès teismo knygos - neikainojamos vertès bajorijos gyvenimo teisminès briaunos atspindys. Jos mums yra dvigubai vertingesnès dar ir todèl, kad, be juridinių-procesinių dalykų, jose fiksuojama ir daugybė notarinių dalykų ar šiaip gyvenimiškos kasdienybės faktų. Kartu teisminių skundų ar nuostolių įrašymas ị žemès teismo knygas rodo ir norą turèti teisminius svertus besibylinėjant su skriaudikais. Šie momentai byloja svarbų bajoriškos savimonès - teisinès kultūros formavimąsi ir stiprèjimą. Straipsnyje aptariama medžiaga sudaro prielaidas platesniam visos LDK teritorijos žemès teismo knygų medžiagos apibendrinimui ateityje.

\section{PRIEDAS}

Gardinas, 1591 I 21 / Orša, 1589 V 29 / Naugardukas, 1588 VI 2 d., L. 337-339 (BNIA, f. 1755, ap. 1, b. 11). Skyrybų proceso tarp Vitebsko vaiskio Levo Sapiegos ir jo žmonos Gannos Kopcevnos užrašymas. Rašto iš Oršos žemės teismo knygos užrašymas. Jị atnešè aktuoti Gardino žemès teisėjas Levas Sapiega. Minimas Oršos žemės teismas, prieš kurị stojo Vitebsko vaiskis Levas Michailovičius Sapiega ir aktavo išrašą iš dvasinių knygų, įrašytą i Gardino žemès teismo knygas:

(337v) [...] Выпис с книг велебног(о) в Бозе его милости архиепископа митрополита Онисидора. Лета от нароженя сына Божего тисеча пя $m$ com осмдесят осмого, м(е)с(е)ца июня второго дня. Перед его милостю архиепископом митрополитом Киевским, Галицким и всея Руси Онисидором Петровичом и всим духовенством его м(и)л(ости) собору Новгородского, а при его м(и)л(остю) на тот час был велебный в Бозе епископ Пинский и Туровскиц̆, отецъ Леонтей Зеновевичъ Пелчыцкий. Постановившысе очывисто велможный п(а)нъ Левъ Сапега, войский Витебский и ее милост велможная п(а)ни Ганна Борисовна Коптевна, сами обедве особы доброволне и очывисто сознали и дали его м(и)л(ости) справу тыми словы, иж што их милость недавно минулы $x$ часов, небудучы ведоми близкое повинности и кревности з собою, отдали се в стан светыц̆ малженский, в котором вод(л)е закону хрестиянског(о) для такое причыны помененое, если бы се им в том стане малженском мешкати годило, о розсудок его м(и)л(ости) и о блогославенство просили. Яко ж и с нею уроженя своего перед его (338) милостю архиепископом покладали и того водлуг права духовного свядецтвом устным и под сумненем доводили и ясне то оказали, иж водлуг тое линии в третим поколеню межы собою их милость суm у повинъности. И просили его м(и)л(ость) архиепископа, ижбы его милост и $x$ в том стане малженском ку мешканю блогославил. Его милост архиепискоn митрополит и все духовенство, при его милости будучое, по достатку с тое справы зрозумели, яко ж в той линеи достаточне ест описано и доложоно, угленувшы и того свядеиства выслухавъшы, в той справе згажаючысе на перед с правом Божым и с правом духовным которые бороня $m$ и не позволяют в такъ близкой повинности в малженство злучатисе и не толко в третим, але и в четвертомъ поколеню малженства не допускает и писмо Святое боронит. Але иж се тое злучене в малженство особу поменены $x$ в так близкой повинности в неведомости стало, его милост аръхиеписко м митрополи $m$, неотступючы того писма Божего и права духовного, которое меновите описует водлуг правил светыхъ Отецъ, у грани третейнадцат, глава четвертая, а на другом местцу у правилах светых Апостол у главе двесте тридцат 
шостой достаточне описует водлуг того духовного права и писма Божего, его милость Архиепископ и за всим духовенством узнавал, иж не было малженство, которое се водлуг писма Божего и назвати малженством не годит. Про то его милост и все духовенство при его м(и)л(ости) будучые, не маючы того з розсудку своего духовного за малженство, але розвезавшы тотъ шлюбъ, волными их обеюх от малженства чынит и блогославляет его милости п(а)ну Лву Михайловичу Сапезе женитисе, а п(а)ни Ганне Борисовне Коптевне так же волно будет замуж пойти. А вжо от сего часу до животов своих зъ их милости одно другому омешкане 3 собою (338v) в стане малженском через сью росправу, очывисте перед его милостю аръхиепископом митрополитом вделаную, не мает припоминаня чынити, ани се 3 собою в обычай малженства злучат, якож их милост межы собою особливые листы на розводъ водлуг обычаю права посполитого свецкого особливе один другому дан и на враде Новгородском сознали и тые листы их милости межы собою даные передо мною покладали. В которы $x$ шырей и достаточне описано и доложоно естъ. А который бы с них сюю росправу в той справе промежку их милости особъ двух помененых взрушыти хотел, тот неблогослевенство от его милости архиепископа на собе носити будет, и яко непослушный права Божего и розсудку духовного от церкви Божией отлучон быти мает. А пани Ганна Коптевна вызнала то доброволне, нехотечы ани маючы воли ни за кого замуж ити, толко в боязни Божой жывота своего доконати. А его милости пану Лву Сапезе и сама доброволне позволила кого хотя в стан малженский за себе взет, на што их милост обедве стороне перед его милостю и судом духовным сами устне зезволившы просили, абы тая справа их милости до книг его м(и)л(ости) духовны $x$ была записана, што ест п(а)ну Лву Сапезе, войскому Витебскому под печатю и с подписом руки его м(и)л(о)сти отца митрополита ест выдан. Писан у Новгородку. <...>

Gauta 20131214

Priimta 20140223

\section{Šaltiniai ir literatūra}

[1] Pirmoji Brastos (1580) žemès teismo knyga. Baltarusijos nacionalinis istorijos archyvas (toliau - BNIA), f. 1741, ap. 1, b. 1.

[2] Antroji Brastos (1584) žemès teismo knyga. BNIA, f. 1741, ap. 1, b. 2.

[3] Trečioji Brastos (1586) žemès teismo knyga. BNIA, f. 1741, ap. 1, b. 3.

[4] Ketvirtoji Brastos (1590) žemès teismo knyga. BNIA, f. 1741, ap. 1, b. 4.

[5] Penktoji Brastos (1591) žemès teismo knyga. BNIA, f. 1741, ap. 1, b. 5.

[6] Šešiasdešimt pirmoji Brastos (1566-1604) žemès teismo knyga. BNIA, f. 1741, ap. 1, b. 61.

[7] Šešiasdešimt trečioji Brastos (1597) žemès teismo knyga. BNIA, f. 1741, ap. 1, b. 63.

[8] Trečioji Gardino (1566-1597) žemès teismo knyga. BNIA, f. 1755, ap. 1, b. 3.

[9] Ketvirtoji Gardino (1568-1570) žemès teismo knyga. BNIA, f. 1755, ap. 1, b. 4.

[10] Penktoji Gardino (1567) žemès teismo knyga. BNIA, f. 1755, ap. 1, b. 5.

[11] Šeštoji Gardino (1571) žemès teismo knyga. BNIA, f. 1755, ap. 1, b. 6.

[12] Septintoji Gardino (1578-1579) žemès teismo knyga. BNIA, f. 1755, ap. 1, b. 7.

[13] Aštuntoji Gardino (1581-1582) žemès teismo knyga. BNIA, f. 1755, ap. 1, b. 8.

[14] Devintoji Gardino (1583-1584) žemès teismo knyga. BNIA, f. 1755, ap. 1, b. 9.

[15] Dešimtoji Gardino (1585-1586) žemès teismo knyga. BNIA, f. 1755, ap. 1, b. 10.

[16] Vienuoliktoji Gardino (1591-1592) žemès teismo knyga. BNIA, f. 1755, ap. 1, b. 11. 
[17] Dvyliktoji Gardino (1592-1593) žemès teismo knyga. BNIA, f. 1755, ap. 1, b. 12.

[18] Tryliktoji Gardino (1594-1596) žemès teismo knyga. BNIA, f. 1755, ap. 1, b. 13.

[19] Keturioliktoji Gardino (1596-1597) žemès teismo knyga. BNIA, f. 1755, ap. 1, b. 14.

[20] Penkioliktoji Gardino (1597) žemès teismo knyga. BNIA, f. 1755, ap. 1, b. 15.

[21] Šešioliktoji Gardino (1599-1601) žemès teismo knyga. BNIA, f. 1755, ap. 1, b. 16.

[22] Pirmoji Slanimo (1565-1566) žemès teismo knyga. BNIA, f. 1785, ap. 1, b. 1 (publikuota, žr. $A B A K$, t. 22, p. 147-301).

[23] Antroji Slanimo (1567-1570) žemès teismo knyga. BNIA, f. 1785, ap. 1, b. 2.

[24] Trečioji Slanimo (1570) žemès teismo knyga. BNIA, f. 1785, ap. 1, b. 3 (publikuota, žr. ABAK, t. 22, p. 302-445).

[25] Ketvirtoji Slanimo (1571) žemès teismo knyga. BNIA, f. 1785, ap. 1, b. 4.

[26] Penktoji Slanimo (1575) žemès teismo knyga. BNIA, f. 1785, ap. 1, b. 5.

[27] Šeštoji Slanimo (1581) žemès teismo knyga. BNIA, f. 1785, ap. 1, ap. 6.

[28] Septintoji Slanimo (1583) žemès teismo knyga. BNIA, f. 1785, ap. 1, ap. 7.

[29] Aštuntoji Slanimo (1583) žemès teismo knyga. BNIA, f. 1785, ap. 1, b. 8.

[30] Devintoji Slanimo (1586) žemès teismo knyga. BNIA, f. 1785, ap. 1, b. 9.

[31] Dešimtoji Slanimo (1588) žemès teismo knyga. BNIA, f. 1785, ap. 1, b. 10.

[32] Vienuoliktoji Slanimo (1589-1590) žemès teismo knyga. BNIA, f. 1785, ap. 1, b. 11.

[33] Dvyliktoji Slanimo (1591) žemès teismo knyga. BNIA, f. 1785, ap. 1, b. 12.

[34] Tryliktoji Slanimo (1593-1594) žemès teismo knyga. BNIA, f. 1785, ap. 1, b. 13.

[35] Keturioliktoji Slanimo (1595) žemès teismo knyga. BNIA, f. 1785, ap. 1, b. 14.

[36] Penkioliktoji Slanimo (1597-1598) žemès teismo knyga. BNIA, f. 1785, ap. 1, b. 15.

[37] Šešioliktoji Slanimo (1598) žemès teismo knyga. BNIA, f. 1785, ap. 1, b. 16.

[38] Septynioliktoji Slanimo (1599) žemès teismo knyga. BNIA, f. 1785, ap. 1, b. 17.

[39] Pirmoji Vitebsko (1594-1596) žemès teismo knyga. BNIA, f. 1751, ap. 1, b. 1.

[40] Antroji Vitebsko (1595-1596) žemès teismo knyga. BNIA, f. 1751, ap. 1, b. 2.

[41] Trečioji Vitebsko (1598) žemès teismo knyga. BNIA, f. 1751, ap. 1, b. 3.

[42] DRUNGILAS, Jonas. Etnosocialinis mobilumas Lietuvos Didžiojoje Kunigaikštysteje: Gruževskių giminès pavyzdys (XVI a. antroji pusė - XVIII a. pradžia). Lietuvos istorijos metraštis, 2004, 2. Vilnius, 2005, p. 53-78.

[43] EITMAITYTĖ, Elena. Vytauto Didžiojo universiteto Rankraščių skyrius. Bibliografijos žinios, 1936, Nr. 1(49), p. 27-30.

[44] GORODECKAS, Eduardas. Žemès teismo genezès Lietuvos Didžiojoje Kunigaikštystėje klausimu. Iš: Jaunujų istoriku darbai. Respublikines jaunuju istorikų mokslinès konferencijos tezès. $1980 \mathrm{~m}$. gegužè. Trečioji knyga. Vilnius, 1980, p. 116-119.

[45] KIAUPIENĖ, Jūratė. Vilniaus vietininko Stanislavo Hamšiejaus 1559-1564 m. teismo knygos. Lietuvos miestu istorijos šaltiniai. T. 2. Vilnius, 1992, p. 61-75.

[46] KIAUPIENĖ, Jüratè. XVI a. ikireforminio Vilniaus pilies teismo knygos-kopijos Lietuvos Metrikoje struktūrinè ir informacinè analizè. Lietuvos Metrika. 1991-1996 m. tyrinejimai. Vilnius, 1998, p. 36-92.

[47] LULEWICZ, Henryk. Sąd ziemski brasławski w świetle zachowanych ksiąg ziemskich z lat 1603-1632. Miscellanea Historico-Archivistica. T. X. Warszawa, 1998, s. 151-161.

[48] MIENICKI, Ryszard. Archiwum akt dawnych Wilnie. Warszawa, 1923.

[49] MONIUSZKO, Adam. Mazowieckie sądy ziemskie (1588-1648). Organizacja-funkcjonowaniepostępowanie. Warszawa, 2013.

[50] Polski Slownik Biograficzny. Warszawa-Krakow, 1994, s. 83-84. 
[51] SAVIŠČEVAS, Eugenijus. Žemaitijos savivalda ir valdžios elitas 1409-1566 metais. Vilnius, 2010. [52] TRIMONIENĖ, Rita Regina. Bajorų luomo vedybinių ryšiu atspindžiai Žemaičių žemès ir pilies teismo aktuose. XVI a. II pusè - XVII a. pirma pusè. Istoriniai tekstai ir vietos kultūra. ŠiauliaiRyga, 2004, p. 167-178.

[53] Urzędnicy Wielkiego Księstwa Litewskiego. Spisy. Tom I: Województwo Wileńskie, XIVXVIII wiek. Warszawa, 2004.

[54] Urzędnicy Wielkiego Księstwa Litewskiego. Spisy. Tom II: Województwo Trockie, XIV-XVIII wiek. Warszawa, 2009.

[55] VALIKONYTĖ, Irena. Priešteisminių dokumentų funkcijos ir likimas Lietuvos Didžiojoje Kunigaikštystėje XVI a. viduryje. Istorijos šaltiniu tyrimai. T. 4. Vilnius: Lietuvos istorijos institutas, p. 93-108.

[56] VILIMAS, Darius. Kauno žemès teismas paskutiniais Stepono Batoro valdymo metais (tematinio tyrimo metmenys). Lituanistica, 2011, t. 57, Nr. 3(85), p. 227-242.

[57] VILIMAS, Darius. Lietuvos Didžiosios Kunigaikštystès žemès teismų funkcija - tarp notariato ir teismo (iki 1589 m.) (lietuviškų pavietų atvejis). Lituanistica, 2011, t. 57, Nr. 4(86), p. 355-364.

[58] VILIMAS, Darius. Lietuvos Didžiosios Kunigaikštystès žemès teismo sistemos formavimasis (1564-1588). Vilnius, 2006.

[59] VILIMAS, Darius. Teisminès kultūros atspindžiai Kauno pavieto žemès teismuose XVI a. devintajame dešimtmetyje. Iš: Lietuvos Didžiosios Kunigaikštystés istorijos kraštovaizdis. Mokslinių straipsnių rinkinys, skirtas prof. J. Kiaupienès 65-mečiui. Vilnius, 2012, p. 503-524.

[60] VILIMAS, Darius. Upytès pavieto žemès teismo elitas ir žemės teismo kasdienybė (15661588). Iš: Iš Panevėžio praeities. Upytés žemei 750 metų. Konferencijos pranešimai, Panevėžys, 200409 14. Panevėžys, 2004, p. 70-91.

[61] VILIMAS, Darius. Žemės teismo knygų, išlikusių Baltarusijos nacionaliniame istorijos archyve Minske, apžvalga iki 1600 m. Lietuvos istorijos metraštis, 2012, 1, 2013, p. 165-176.

[62] VILIMAS, Darius. Bajorai Upytes pavieto teisme pagal žemès teismo knygas (paskutinysis XVI a. dešimtmetis), Lituanistica, 2013, t. 59, Nr. 1(91), p. 1-8.

[63] ZAKRZEWSKI, Andrzej Wielkie Księstwo Litewskie (XVI-XVIII w.). Prawo-ustrój-społeczeństwo. Warszawa, 2013.

[64] Акты, издаваемые Виленскою археографическою коммиссиею для разбора древних актов (toliau - ABAK). Т. 22: Акты Сланимскаго земскаго суда. Вильна, 1895, с. 147-301.

[65] АВАК. Т. 22: Акты Сланимскаго земскаго суда. Вильна, 1895, с. 302-445.

[66] КАПЫСКІ, Сяргей. Увядзенне земских судоу паводле земскай рэформы 1565-1566 г. (на прыкладзе Слонімскага павета). Леу Сапега (1557-1633 г.) $і$ яго час. Гародня: ГрДУ, 2007, c. 106-110.

[67] ЛАППО, Иван. Земский суд в Великом Княжестве Литовском в конце XVI в. Журнал Министерства Народного Просвещения, 1897, VI, с. 263-301.

[68] ЛАППО, Иван. Великое Княжество Литовское за время от заключения Люблинской унии до смерти Стефана Батория. Опыт исследования политического и общественного строя. Ч. І. Санкт-Петербург, 1901.

[69] ЛАППО, Иван. Великое Княжество Литовское во второй половине XVI столетия. Литовско-русский повет и его сеймик. Юрьев, 1911.

[70] Луцяка замкова книга 1560-1561. Підготували до виданя В. Т. Мойсиенко, В. В. Поліщук. Луцк, 2013.

[71] Опись документов Виленского Центрального Архива древних актовых книг. Выпуски I-V. Вильна, 1901-1905. 
[72] ПОЛІЩУК, Володимир. Между процедурой и формуляром: источниковедческий анализ судебных записей замковых книг перед реформой 1564-1566 гг. (на примере луцких замковых книг 1558-1566 гг.). Ǐs: Lietuvos Didžiosios Kunigaikštystés istorijos šaltiniai. Faktas. Kontekstas. Interpretacija. Vilnius: LII 1-kla, 2007, p. 355-380.

[73] ПОЛІЩУК, Володимир. Луцький замковий уряд в адмінистративній системі Великого князівства Литовского до реформ 1564-1566 рр. Україньский історичний журнал. Київ, 2003, №. 2, с. 3-13; 2005, №. 1, с. 80-124.

[74] РАДАМАН, Андрей. Арганізацыя и склад полацкога земскага суда ў другой палове XVI-першай трэці XVII ст. ГЕРОЛД-LITHERLAND. Горадня-Менск, 2011, №. 18, с. 21-36.

[75] Тастаменты шляхты і мяччан Беларусі другой паловы XVI cm. (з актавых кніг Нацыянальнага гістарычнага архіва Беларусі). Мінск, 2012.

[76] ШАЛАНДА, Алексей. Земскі суд Гарадзенскага павета ў 1555-1564 гг. Гарадзенскі палімпсест. 2009. Дзяржауныя установы і палітычнае жыице. XV-XX стст. Гародня, 2009, c. 35-64.

[77] ШАЛАНДА, Алексей. Дарэформенны земскі суд Гарадзенскага павета ў 1562-1564 гг. Гарадзенскі палімпсест. 2010. Асоба, грамадства,дзяржава жыцие. XV-XX стст. Гародня, 2011, c. 45-56.

[78] СЛІЖ, Наталия Вяноуныя запісы ў кнізе Гараденскага земскага суда за 1578-1579 гг. Гародзенскі палімпсест. Дзяржауныя установы і палітычнае жыцие у XV-XX стст. Гародня, 2009, с. 65-74.

[79] СПИРИДОНОВ, Михаил. Завершение формирования Пинского повета в 1566 г. Навук.-практ. канф., присвеч. 900-годдзю Пінска, Май 1997 г. Пінск, 1997, с. 8-11.

[80] СТАРЧЕНКО, Наталия. Вбиство князів Четвертинских 1576 р.: судовий процес та замиреня на Волини в кинці XVI ст. СОЦІУМ. Альманах соизальної історїі, 2007, випуск 7, c. 83-110.

[81] СТАРЧЕНКО, Наталия. Судова реторика як вияв цінностей волинскої шляхти кінця 16 ст. (на приклади справи про вбивство Балтазара Гнівоша з Олексова). СОЦІУМ. Альманах соціальної исторії, 2010, випуск 9, с. 318-360.

\section{Nobles in the land court books of Belarusian districts of the Grand Duchy of Lithuania. Legal aspects}

Summary

The article analyses manuscript land court books of the districts of the Grand Duchy of Lithuania (GDL) surviving in the National Historical Archives of Belarus in Minsk. The archives are home to 41 manuscript land court books of the so called "Belarusian" (Brest, Grodna, Slonim and Vitebsk) post-reform districts of the GDL (until 1600). The books stand out by their thematic diversity but their content differs from the material of equivalent districts of the Lithuanian part of the GDL only marginally. The books under discussion constitute a quantitative and qualitative supplement to the material of land court books of Lithuanian districts of the GDL, enabling a more in-depth coverage of the work of land courts and the activities of the nobility in them and composing a panorama of all land courts in the GDL of that time. 
Like the Lithuanian part of the GDL, the records in the land court books of "Belarusian" districts can be subdivided into notarial and judicial-procedural. Notarial records dominate in the majority of the books under analysis. The given examples of the records from the books indicate that district land court books could also record such documents which were not directly related to court functions or belonged to the competence of a different district court. Even though nearly all land court books contain some judicial-procedural records, the number of court judgements is usually rather low and makes up from one-fifth to one-third of all non-notarial records in the books. The article provides a relatively rare group of land court records - family disputes; one divorce document is fully re-recorded in the supplement to the article.

Manuscript district land court books of the GDL are an especially valuable reflection of the judicial aspect in the life of the nobility. They are made twice as interesting for us by the fact that in addition to judicial-procedural matters, they record a number of notarial issues or daily facts of the nobility. In addition to the aforesaid, the recording of judicial complaints or losses in land court books shows the intention to have a judicial advantage in the litigation with offenders. These moments show an important formation and strengthening of legal culture in the noble self-consciousness. The material discussed in the article creates preconditions for a broader generalisation of the material of land court books from the entire territory of the GDL in the future.

Key words: district land courts in GDL, content of land court books, legal culture, nobility of GDL 